\title{
ANTESEDEN KEPUTUSAN PEMBELIAN ONLINE KONSUMEN ALFACART
}

\author{
Bagus Manunggal \\ Universitas Islam Syekh Yusuf \\ bagusmanunggal@unis.ac.id \\ https://doi.org/10.33592/jeb.v26i1.662
}

\begin{abstract}
ABSTRAK
Pada pertengahan tahun 2017, Alfacart menyesuaikan model bisnisnya menjadi hanya berfokus pada penjualan produk-produk groceries. Penyesuaian tersebut berimbas pada pengurangan karyawan sekitar 50\%. Data iprice.co.id pada Q4 2017 menunjukkan Alfacart hanya menempati peringkat 18 dari keseluruhan e-commerce yang ada di Indonesia. Kondisi tersebut diperparah dengan adanya penurunan daya beli oleh masyarakat. Berdasarkan latar belakang tersebut, penulis ingin mengkonfirmasi korelasi dari kualitas website, kepercayaan konsumen, dan kesadaran merek terhadap keputusan pembelian di Alfacart, baik korelasi parsial maupun korelasi keseluruhannya. Penelitian ini melibatkan 100 responden yang merupakan konsumen yang pernah berbelanja di Alfacart yang peneliti ambil secara acak. Penulis memanfaatkan Google Form untuk membuat kuesioner agar mudah dalam menjangkau responden dan memudahkan responden untuk mengisi kuesioner. Analisa yang penulis gunakan adalah korelasi Spearman dengan bantuan Microsoft Excel 2013. Penelitian ini menunjukkan bahwa ada korelasi yang cukup signifikan antara kualitas website, kepercayaan konsumen, dan kesadaran merek terhadap keputusan pembelian oleh konsumen, baik pada korelasi parsial maupun korelasi keseluruhan.
\end{abstract}

Kata Kunci: e-Commerce; Alfacart; keputusan pembelian.

\begin{abstract}
In mid 2017, Alfacart adjusted its business model to focus solely on selling groceries products. The adjustment has an impact on employee reduction of about 50\%. Data on iprice.co.id in Q4 2017 shows Alfacart is ranked 18th of all e-commerce in Indonesia. This condition is exacerbated by the decline in purchasing power by the public. Based on this background, the author wants to confirm the correlation of website quality, consumer trust, and brand awareness with purchasing decisions at Alfacart, both partial and overall correlations. This study involved 100 respondents who were consumers who had shopped at Alfacart which researchers took at random. The author uses Google Form to make a questionnaire so that it is easy to reach respondents and make it easier for respondents to fill out questionnaires. The analysis that author use is Spearman correlation with the help of Microsoft Excel 2013. This research shows that there is a significant correlation between website quality, consumer trust, and brand awareness of consumer purchasing decisions, both in partial and overall correlations.
\end{abstract}

Keywords: e-Commerce; Alfacart; purchase decision.

\section{A. Pendahuluan}

Alfacart merupakan transformasi dari Alfaonline dengan mengusung konsep marketplace. Perbedaannya, Alfacart menambah kategori produk-produk yang dijualnya, tidak hanya produk-produk groceries namun ada juga gadget, elektronik, fashion, dan lain sebagainya.

Berubahnya intensi menjadi full $e$ commerce dari sebelumnya hanya online channel Alfamart, maka dilakukan rebranding dari Alfaonline menjadi Alfacart pada tahun 2016. Meski terlambat dalam memasuki industri marketplace, namun Alfacart optimis mampu bersaing. Segmen pasar Alfacart adalah usia 2535 tahun, dengan kelas ekonomi menengah, dan dengan profesi karyawan, ibu rumah tangga, dan pelajar. Toko-toko Alfamart dimanfaatkan oleh Alfacart untuk payment point, pickup barang oleh konsumen, dan drop off barang oleh penjual (Putri, 2016).

Namun pada Maret 2017, Alfacart mengeluarkan kebijakan efisiensi. Kebijakan ini berdampak pada pengurangan beberapa karyawan. Berlanjut pada pertengahan 2017 Alfacart melakukan restrukturisasi pimpinan dan pengurangan karyawan. Sekitar 50 persen 
karyawan termasuk level pimpinan diberhentikan (Pratama, 2017; Santhika, 2017). Dijelaskan oleh Direksi Alfamart bahwa Alfacart mengubah model bisnisnya dari sebelumnya full e-commerce menjadi digital extension channel bagi Alfamart.

Perubahan tersebut berdampak pada restrukturisasi organisasi. Bahkan C-Level ikut mengundurkan diri, namun tetap men-support proyek strategis Alfa Group (Pratama, 2017). Setelah perubahan model tersebut, berdasarkan data iprice.co.id pada Q4 2017, Alfacart menempati peringkat 18 dari 37 marketplace di Indonesia dari sebelumnya peringkat 6 pada Q1 2017 (iPrice Group Sdn Bhd, 2017).

Kondisi seperti itu diperparah dengan penurunan daya beli oleh masyarakat. Fakta ini didasari oleh penurunan daya beli pada kwartal 12017 bila dibandingkan kwartal 3 2016. Laju inflasi pada Maret dan April 2017 juga minus. Data tersebut menunjukkan bahwa benar terjadi penurunan daya beli masyarakat (Andreas, 2017).

Berdasarkan fenomena tersebut, peneliti ingin menganalisa keputusan pembelian oleh konsumen Alfacart. Sejauh penelusuran peneliti, belum ada penelitian mengenai korelasi kualitas website, kepercayaan konsumen, dan kesadaran merek, dengan keputusan pembelian konsumen Alfacart.

Apakah terdapat korelasi faktor kualitas website, kepercayaan konsumen, dan kesadaran merek baik secara parsial maupun simultan dengan keputusan pembelian online konsumen Alfacart?

Tujuan penulis ingin menganalisa dan mengetahui korelasi faktor kualitas website, kepercayaan konsumen, dan kesadaran merek secara simultan dengan keputusan pembelian online konsumen Alfacart.

\section{Tinjauan Pustaka}

\section{Kualitas Website}

Berdasarkan penelitian sebelumnya (Afshardost, 2013), fitur-fitur yang sesuai kebutuhan pelanggan dan keunggulan website menjadi dasar penentu kualitas website. Penelitian tersebut memasukkan keamanan, hiburan, kualitas informasi, kemudahan penggunaan, dan kualitas layanan sebagai dimensi kualitas website. Kualitas layanan melalui website yang ditawarkan pada pelanggan dan fitur-fiturnya ditentukan oleh desain website. Berdasarkan penelitian Attributable E-commerce toward Purchase Intention: Online Search of Food Product (Rozekhi et al., 2016), disebutkan bahwa tampilan estetika, navigasi, dan tampilan konten yang terorganisir dan dikelola dengan baik merupakan faktor penting dalam desain website.

Sedangkan berdasarkan penelitian Web qual: a measure of website quality (Loiacono et al., 2004), terdapat 5 indikator kualitas website yang didapat dari studi literatur dan wawancara pengunjung dan desainer website, yaitu kemudahan penggunaan, kemanfaatan, hiburan, hubungan komplementer, pelayanan konsumen.

\section{Kepercayaan}

Kepercayaan, berdasarkan The Chain of Effects from Brand Trust and Brand Affect to Brand Performance: The Role of Brand Loyalty (Chaudhuri \& Holbrook, 2001), merupakan kemauan mayoritas konsumen untuk bergantung pada kemampuan suatu merek karena kinerja yang dijanjikan atau ditawarkan oleh merek tersebut. Kepercayaan konsumen terhadap layanan website (e-trust), menurunkan ketidakpastian pada konsumen dalam menggunakan layanan tersebut.

Pada beberapa penelitian sebelumnya (Featherman, 2001; van der Heijden et al., 2003), resiko yang dirasakan oleh konsumen pada pembelian online berbanding terbalik dengan kepercayaan. Semakin konsumen percaya pada transaksi online, semakin kecil resiko yang dirasakan. Sedangkan, semakin tinggi resiko yang dirasakan akan berpengaruh negatif terhadap perilaku belanja online.

Pada penelitian Pengaruh Kepercayaan Kualitas Informasi Dan Pelayanan Terhadap Keputusan Membeli Melalui Media Sosial ( Studi Kasus Mahasiswa Akuntansi STIE MDP ) (Khairani, 2015), indikator untuk variabel kepercayaan mencakup Kredibilitas, Keandalan Penjual, Kepedulian, Keamanan, Kerahasiaan, Kompensasi Kerugian, Citra Penjual, dan Kejujuran Penjual.

\section{Kesadaran Merk}

Menurut William dan Jerome dalam Basic Marketing (Perreault \& McCarthy, 2002), kesadaran merek adalah seberapa baik pelanggan mengenal dan menerima merek perusahaan. Tingkat kesadaran merek akan mempengaruhi ’perencanaan bauran pemasaran. 
Terdapat lima tingkatan kesadaran merek, yaitu ditolak, tidak dikenali, dikenali, dipilih, dan diinginkan.

Menurut Philip Kotler dalam Marketing Management (Kotler \& Keller, 2015), kesadaran merek adalah tingkatan kemampuan konsumen untuk mengetahui dan mengenali merek dalam suatu kategori. Mengetahui lebih mudah untuk dicapai daripada mengenali. Pengenalan merek berperan penting pada luar toko, sedangkan pengetahuan merek berperan penting di dalam toko.

Dari pengertian tersebut di atas dapat disimpulkan bahwa kesadaran merek adalah kemampuan customer untuk mengetahui dan mengenali merek.

\section{Keputusan Pembelian}

Belanja online adalah bentuk perdagangan elektronik yang digunakan pada transaksi business-to-business (B2B) dan business-to-consumer (B2C). Keputusan membeli secara online dipengaruhi oleh (Devaraj et al., 2003):

1. Efisiensi untuk pencarian (waktu cepat, mudah dalam penggunaan, dan usaha pencarian mudah),

2. Value (harga bersaing dan kualitas baik), dan

3. interaksi (informasi, keamanan, load time, dan navigasi).

Adapun indikator dari keputusan pembelian, yaitu (Kotler \& Keller, 2015):

1. Kemantapan pada sebuah produk

2. Kebiasaan dalam membeli produk

3. Memberikan rekomendasi kepada orang lain

4. Melakukan pembelian ulang

\section{Korelasi Kualitas Website dengan Keputusan Pembelian}

Penelitian Amit Poddar, Naveen Donthu, dan Yujie Wei membuktikan bahwa ada relasi positif Kualitas Website dengan Keputusan Pembelian dengan nilai $\mathrm{t}$-value $=4.13$ (Poddar et al., 2009). Nilai tersebut diperoleh dari 460 responden yang mengunjungi 22 website yang menjual produk-produk pakaian. Data yang diperoleh kemudian diolah dengan Lisrel 8.54 dan pengujian hipotesanya dengan OLS.

\section{Korelasi Online Trust dengan Keputusan Pembelian Online}

Penelitian Kwek Choon Ling, Lau Teck Chai, dan Tan Hoi Piew menghasilkan bahwa Online Trust berpengaruh positif terhadap Keputusan Pembelian Online dengan nilai pvalue untuk Online Trust $(\mathrm{p}=0.000)$ kurang dari alpha value 0.05 (Ling et al., 2010). Nilai tersebut diperoleh dari 242 responden di sebuah universitas swasta di Malaysia yang pernah melakukan transaksi secara online. Data yang diperoleh diolah dengan regresi linear berganda di SPSS versi 14.

\section{Korelasi Kesadaran Merek dengan Keputusan Pembelian}

Penelitian oleh Hsin Kuang Chi, Huery Ren Yeh, dan Ya Ting Yang menghasilkan bahwa kesadaran merek memberi pengaruh positif pada keputusan pembelian dengan $\beta=0.384$ dan $p<0.001$ (Kuang Chi et al., 2009). Nilai tersebut diperoleh dengan mensurvey 267 reponden kemudian dianalisa dengan regresi.

Kerangka Konsep Dan Hipotesis

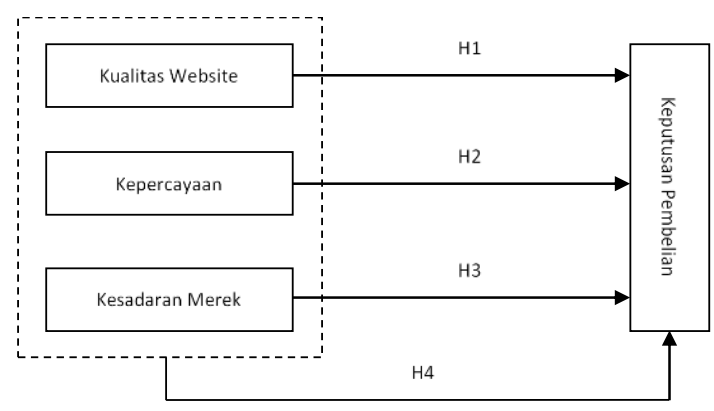

Sumber: Hasil olahan peneliti

Gambar 1. Kerangka Konsep Penelitian H1: Terdapat korelasi positif yang signifikan antara Kualitas Website dengan Keputusan Pembelian

$\mathrm{H} 2$ : Terdapat korelasi positif yang signifikan antara Kepercayaan Konsumen dengan Keputusan Pembelian

H3: Terdapat korelasi positif yang signifikan antara Kesadaran Merek dengan Keputusan Pembelian

H4: Terdapat korelasi positif yang signifikan antara Kualitas Website, Kepercayaan Konsumen, dan Kesadaran Merek dengan Keputusan Pembelian secara bersamaan.

\section{B. Metode Penelitian}

Populasi dari penelitian ini adalah keseluruhan konsumen Alfacart yang pernah berbelanja dan telah menerima barangnya. Pemilihan sampel menggunakan Random 
Sampling. Sedangkan untuk analisanya menggunakan analisa korelasi Spearman untuk mengetahui korelasi dari masing-masing variabel tersebut.

\section{Hasil Dan Pembahasan}

Hasil dari penyebaran kuesioner, hanya 100 kuesioner yang kembali. Data dari kuesioner tersebut peneliti simpan dalam Excel untuk dapat dianalisa. Terdapat 57\% responden wanita dan $43 \%$ pria. Sebanyak $35 \%$ responden melakukan pembelanjaan $>7$ kali dalam 1 (satu) bulan. Mayoritas, 93\% responden, merupakan pekerja, dan $87 \%$ usia di atas 30 tahun.

Berdasarkan hasil tersebut, dapat dikatakan bahwa profil konsumen Alfacart adalah para pekerja muda dan mayoritas kaum hawa. Temuan ini sesuai dengan target pasar Alfacart yaitu pekerja wanita muda, yang menginginkan kepraktisan dalam pemenuhan kebutuhan bulanannya.

Berikutnya, peneliti menghitung korelasi per variabelnya menggunakan Microsoft Excel 2010. Berdasarkan hasil analisa korelasi, koefisien korelasi dengan Keputusan Pembelian pada Kualitas Website sebesar 0.644, pada Kepercayaan 0.69, dan pada Kesadaran Merek 0.58 .

Ketiga variabel tersebut memiliki korelasi searah dan cukup kuat dengan Keputusan Pembelian. Sehingga dapat dikatakan bahwa peningkatan pada masingmasing variabel tersebut dapat mempengaruhi peningkatan pada keputusan pembelian oleh konsumen. Temuan ini mendukung H1, H2, dan H3.

Tabel 1. Hasil Korelasi Parsial

\begin{tabular}{llllll}
\hline \multicolumn{1}{c}{$\mathbf{X 1}$} & \multicolumn{1}{c}{$\mathbf{X 2}$} & \multicolumn{1}{c}{$\mathbf{X 3}$} & $\mathbf{Y}$ \\
\hline $\mathbf{X 1}$ & 1 & & & \\
$\mathbf{X 2}$ & 0.735 & 1 & & & \\
$\mathbf{X 3}$ & 0.655 & 0.677 & 1 & & \\
$\mathbf{Y}$ & 0.644 & 0.690 & 0.580 & 1 & \\
\hline
\end{tabular}

Sumber: Hasil data diolah

Masih menggunakan Excel, berikutnya peneliti melakukan analisa korelasi berganda. Berdasarkan analisa korelasi berganda:

$r_{y . x 1, x 2, x 3}=0.707$
Hasil tersebut menunjukkan bahwa ada korelasi positif dan kuat ketiga variabel independen tersebut dengan variabel dependennya. Temuan ini dapat dikatakan bahwa secara bersamaan, meningkatnya kualitas web, kepercayaan, dan kesadaran merek dapat meningkatkan keputusan pembelian oleh konsumen. Sehingga mendukung $\mathrm{H} 4$.

\section{Implikasi Dan Kesimpulan}

Keputusan pembelian terbukti memiliki korelasi positif dan cukup kuat dengan kualitas web, kepercayaan, dan kesadaran merek.

Hasil korelasi pada masing-masing variabel tersebut dapat dijadikan acuan bagi Alfacart untuk meningkatkan keputusan pembelian oleh konsumen. Alfacart dapat meningkatkan kualitas web, kepercayaan, dan kesadaran merek, untuk meningkatkan keputusan pembelian oleh konsumen.

Penelian berikutnya dapat berfokus pada penelitian variabel-variabel yang mempengaruhi kepercayaan dan kesadaran merek.

\section{E. Daftar Pustaka}

Afshardost, M. (2013). Linking trust, perceived website quality, privacy protection, gender and online purchase intentions. IOSR Journal of Business and Management. https://doi.org/10.9790/487x-1346372

Andreas, D. (2017). Penurunan Daya Beli atau Peralihan Pola Belanja? Tirto.ID. https://tirto.id/penurunandaya-beli-atau-peralihan-pola-belanjacx7Z

Chaudhuri, A., \& Holbrook, M. B. (2001). The Chain of Effects from Brand Trust and Brand Affect to Brand Performance: The Role of Brand Loyalty. Journal of Marketing, 65(2), 81-93.

https://doi.org/10.1509/jmkg.65.2.81.1 8255

Devaraj, S., Fan, M., \& Kohli, R. (2003). Eloyalty. Communications of the ACM, 46(9), https://doi.org/10.1145/903893.903936

Featherman, M. S. (2001). Extending the technology acceptance model by 
inclusion of perceived risk. 2001 Proceedings of Americas Conference on Information Systems.

iPrice Group Sdn Bhd. (2017). Daftar 50 Website \& Aplikasi E-Commerce di Indonesia 2017.

https://iprice.co.id/insights/mapofecom merce/

Khairani, S. (2015). Pengaruh Kepercayaan Kualitas Informasi Dan Pelayanan Terhadap Keputusan Membeli Melalui Media Sosial ( Studi Kasus Mahasiswa Akuntansi STIE MDP ). Seminar Nasional Ekonomi Manajemen Dan Akuntansi (Snema) Fakultas Ekonomi Universitas Negeri Padang. http://fe.unp.ac.id/sites/default/files/un ggahan/22. Siti Khairani (hal 305314)_0.pdf

Kotler, P., \& Keller, K. L. (2015). Marketing Management, Global Edition. Pearson Education Limited. https://books.google.co.id/books?id=o 5YZCgAAQBAJ

Kuang Chi, H., University, N., Huery Ren Yeh, T., Chien University, S., Ya Ting Yang, T., \& Student, G. (2009). The Impact of Brand Awareness on Consumer Purchase Intention: The Mediating Effect of Perceived Quality and Brand Loyalty. In The Journal of International Management Studies (Vol. 4, Issue 1).

Ling, K. C., Chai, L. T., \& Piew, T. H. (2010). The effects of shopping orientations, online trust and prior online purchase experience toward customers' online purchase intention. International Business Research, 3(3), $63 . \quad \mathrm{http}: / / \mathrm{www} \cdot$ polestarschool.com/download/routine039.p df

Loiacono, E. T., Watson, R. T., \& Goodhue, D. L. (2004). Web qual: a measure of website quality. Proceedings of the Winter Educator's Conference, American Marketing Association,
Chicago, 432-437.

Perreault, W. D., \& McCarthy, E. J. (2002). Basic marketing: A global managerial approach. McGraw-Hill/Irwin.

Poddar, A., Donthu, N., \& Wei, Y. (2009). Web site customer orientations, Web site quality, and purchase intentions: The role of Web site personality. Journal of Business Research, 62(4), 441-450.

https://doi.org/10.1016/j.jbusres.2008. 01.036

Pratama, A. H. (2017). Ubah Model Bisnis, Alfacart Pecat CEO dan Ratusan Karyawan.

https://id.techinasia.com/ubah-modelbisnis-alfacart-pecat-ceo-dan-ratusankaryawan

Putri, W. D. (2016). Bertransformasi dari Alfaonline, Alfacart.com Jajaki Marketplace | Republika Online. https://www.republika.co.id/berita/tren dtek/aplikasi/16/06/04/o884t4359bertransformasi-dari-alfaonlinealfacartcom-jajaki-marketplace

Rozekhi, N. A., Hussin, S., \& Noor, A. M. (2016). Attributable E-commerce toward Purchase Intention: Online Search of Food Product. The SIJ Transactions on Advances in Space Research \& Earth Exploration. https://doi.org/10.9756/sijasree/v4i1/0 203410401

Santhika, E. (2017). Gagal, Alfacart Rumahkan 50 Persen Karyawan. https://www.cnnindonesia.com/teknol ogi/20170622141508-185-

223570/gagal-alfacart-rumahkan-50persen-karyawan

van der Heijden, H., Verhagen, T., \& Creemers, M. (2003). Understanding online purchase intentions: contributions from technology and trust perspectives. European Journal of Information Systems, 12(1), 41-48. https://doi.org/10.1057/palgrave.ejis.3 000445 